\title{
Peningkatan Kapasitas Aparatur Pemerintah Daerah dalam Perencanaan Pembangunan (Studi Kasus di lingkungan Pemerintah Kota Probolinggo)
}

\author{
Wahju Krisnanto ${ }^{1}$, Nany Suryawati ${ }^{2}$ \\ 1,2Faculty of Law, Universitas Katolik Darma Cendika \\ Correspondence email: krisnanto.wahju@gmail.com
}

\begin{abstract}
Abstrak. Pemberian kewenangan lebih besar kepada pemerintah daerah untuk melakukan inovasi pembangunan di era otonomi daerah merupakan peluang sekaligus tantangan. Pemberian kewenangan tersebut, memerlukan dukungan kapasitas dari aparatur pemerintah daerah untuk mampu merencanakan kegiatan program pembangunan yang inovatif berdasar pada kebutuhan daerahnya. Dalam faktanya, masih banyak aparatur pemerintah daerah yang belum memiliki kapasitas untuk merencanakan kegiatan program pembangunan yang inovatif. Diperlukan informasi data untuk mengetahui faktor yang menjadi akar penyebab rendahnya kapasitas aparatur pemerintah daerah untuk melakukan perencanaan pembangunan. Tujuan diketahuinya faktor akar penyebab rendahnya kapasitas aparatur pemerintah dalam melakukan perencanaan pembangunan adalah diperolehnya solusi yang dapat dilakukan oleh pemerintah daerah untuk meningkatkan kapasitas aparatur pemerintahannya. Sebagai lokasi penelitian, dipilih wilayah kota Probolinggo. Metode yang dipergunakan dalam penelitian ini mempergunakan pendekatan deskriptif kualitatif. Dari hasil penelitian diketahui adanya beberapa faktor penyebab rendahnya kapasitas aparatur pemerintah daerah adalah belum efektifnya mekanisme evaluasi, tidak ada pendokumentasian dan pengkomunikasian hasil kegiatan program pembangunan, tidak adanya rencana pengembangan SDM, lemahnya data input perencanaan program pembangunan dan cepatnya intensitas mutasi aparat birokrasi.
\end{abstract}

Kata Kunci: Aparatur; Kapasitas; Perencanaan; Pembangunan.

\begin{abstract}
Giving greater authority to local governments to carry out development innovations in the era of regional autonomy is both an opportunity and a challenge. The granting of such authority requires the support of the capacity of the regional government apparatus to be able to plan innovative development program activities based on the needs of the region. In fact, there are still many local government apparatus that do not yet have the capacity to plan innovative development program activities. Data information is needed to determine the factors that become the root cause of the low capacity of local government officials to carry out development planning. The purpose of knowing the root factor that causes the low capacity of government apparatus in carrying out development planning is to obtain solutions that can be done by local governments to increase the capacity of their government apparatus. As a research location, Probolinggo City was chosen. The method used in this study uses a qualitative descriptive approach. The results of the study revealed that there were several factors causing the low capacity of the regional government apparatus, the evaluation mechanism was not effective, there was no documentation and communication of the results of development program activities, lack of Human Resources development plans, weak development program of input data planning and the rapid mutation intensity of bureaucratic apparatus.
\end{abstract}

Keywords: Apparatus; Capacity; Planning; Development.

\section{PENDAHULUAN}

Tumbangnya pemerintahan Presiden Soeharto pada tahun 1998 menyadarkan masyarakat Indonesia, bahwa sistem tata kelola pemerintahan ketika itu sangat rapuh untuk disalahgunakan oleh para birokrat. Kerapuhan sistem tata kelola pemerintahan tersebut menimbulkan penyakit (patologi) di kalangan birokrat di Indonesia yang ditandai terjadinya praktik korupsi, kolusi dan nepotisme (KKN).Terjadi sentralisasi kewenangan dalam tata kelola pemerintahan di Indonesia yang berakibat absolutism kewenangan pada segelintir elit politik di Indonesia.

Sentralisasi kewenangan juga terjadi dalam sistem pemerintahan di Indonesia, dimana sistem kewenangan pemerintahan tersentralisasi pada Pemerintah Pusat. Tidak terjadi pemerataan pembangunan di seluruh wilayah di Indonesia. Wilayah pemerintahan yang jauh dari pusat kekuasaan mendapatkan alokasi dana pembangunan lebih sedikit dibanding dengan wilayah pemerintahan yang dekat dengan pusat kekuasaan. Tidak mengherankan apabila angka indeks persepsi korupsi Indonesia pada tahun 1998 terendah di antara negara-negara ASEAN dengan penduduk miskin sebesar 47,97juta orang pada tahun 1999 (Statistik, 2017).
Menyadari sistem tata kelola pemerintahan Indonesia yang rapuh terhadap praktik KKN, masyarakat menginginkan dilakukannya reformasi sistem tata kelola pemerintahan yang mendasarkan pada prinsip tata kelola pemerintahan yang baik (Good Governance). Implementasi prinsip Good Governance dimulai dengan melakukan desentralisasi kewenangan kepada Pemerintah Daerah yang selama ini porsi kewenangannya banyak dikuasai oleh Pemerintah Pusat. Asas desentralisasi tersebut diwujudkan dengan pemberian otonomi daerah kepada Pemerintah Daerah, baik di tingkat Provinsi, Kabupaten dan Kota. Rondinelli (1983) mendefinisikan otonomi daerah sebagai pemberian kewenangan dari Pemerintah Pusat kepada Pemerintah Daerah terkait politik dan hukum untuk merencanakan, membuat keputusan dan mengelola fungsi publik. Fungsi publik disini tidak saja sebatas pada fungsi pelayanan pemerintahan pada hal-hal yang bersifat administratif, namun juga merencanakan dan melaksanakan pembangunan yang dapat dimanfaatkan oleh publik.

Otonomi daerah bukan sekedar pemberian kewenangan dalam mengatur tata pemerintahan di daerah saja, namun diperlukan kemampuan daerah untuk memahami secara mendalam potensi dan 
permasalahan yang dimiliki daerah serta kebutuhan nyata warganya. Oleh karena itu, aspek perencanaan pembangunan dengan memperhatikan potensi, peremasalahan dan kebutuhan nyata warganya, menjadi kunci awal yang diperlukan dalam pelaksanaan otonomi daerah. Selain daripada itu implementasi Good Governance dalam otonomi daerah juga dapat dimulai dari aspek perencanaan pembangunan. Setidaknya terdapat 2 (dua) alasan diperlukannya perencanaan pembangunan, yaitu tidak adanya kepastian tentang kondisi pada masa mendatang serta untuk memberikan arah pembangunan. Tanpa arah pembangunan yang pasti, maka pemerintah mengalami kesulitan untuk menetapkan langkah dan prioritas pembangunan yang diambilnya. Sebagai akibatnya, anggaran pembangunan terbuang sia-sia tanpa dapat memberikan manfaat sebesarnya bagi kesejahteraan warga.

Menyadari pentingnya aspek perencanaan dalam sistem tata kelola pemerintahan yang baik, Pemerintah pada tahun 2004 telah menerbitkan UU No. 25 Tahun 2004 tentang Sistem Perencanaan Pembangunan Nasional. Melalui undang-undang ini diatur sistem perencanaan pembangunan yang menghasilkan rencana pembangunan jangka panjang, jangka menengah maupun tahunan yang dilakukan oleh semua unsur pemerintahan, Telah pula diamanatkan dalam undang-undang ini, bahwa perencanaan pembangunan harus bersifat terkoordinatif, sinergis dan komprehensif. Koordinasi dan sinergitas tidak hanya terjadi di antar organisasi perangkat daerah (OPD), antar wilayah pemerintah daerah dan hirarki pemerintahan (pusat, provinsi dan kabupaten/kota), namun juga melibatkan berbagai pemangku kepentingan di wilayah pemerintah daerah.

Selain pada aspek perencanaan, isu sentral implementasi otonomi daerah adalah pada kesiapan aparatur pemerintah daerah dalam menjalankan seluruh kebijakan otonomi daerah. Hal ini seperti yang disampaikan oleh Cheema dan Rondinelli dalam bukunya yang berjudul "Decentralization and Development: Policy Implementation in Developing Countries" yang menyatakan bahwa kapasitas aparatur dalam manajerial dan administratif pembangunannya, khusus pada aspek perencanaan, pengendalian dan pengintegrasian pembangunan sangat berperan dalam implementasi otonomi daerah (Cheema \& Rondinelli, 1983, 26-27).

Kapasitas aparatur pemerintah daerah dalam perencanaan pembangunan menjadi isu sentral dalam implementasi otonomi daerah. Hal ini karena kemampuan aparatur pemerintah daerah menjadi pilar penyangga dalam penyelengaraan pemerintah daerah (Listyodono \& Purwaningdyah MW, 2008).

Telah banyak program reformasi birokrasi, khususnya terkait dengan peningkatan kapasitas birokrasi dalam perencanaan pembangunan yang telah dilakukan Pemerintah. Namun dalam pelaksanaannya, belum cukup memberikan hasil yang maksimal. Hal ini diindikasikan dengan adanya beberapa fenomena yang terjadi dalam perencanaan pembangunan, antara lain masih banyaknya perencanaan pembangunan yang hanya mengacu pada perencanaan pembangunan tahun lalu tanpa mendasarkan pada kebutuhan nyata masyarakat yang ada di daerah. Sebagai akibatnya, pembangunan menjadi tidak efektif, efisien dan stagnan.

Rendahnya kapasitas SDM aparatur dalam implementasi kebijakan otonomi daerah juga ditemukan dari hasil penelitian yang dilakukan oleh Seymor dan Turner (2002) yang menyatakan bahwa kemampuan SDM di tingkat eksekutif dan legislatif di daerah di Indonesia dalam rangka implementasi kebijakan otonomi daerah dirasa belum siap.

Artikel ini disusun untuk memberikan kontribusi reformasi birokrasi, khususnya untuk peningkatan kapasitas aparatur pemerintah daerah dalam melakukan perencanaan pembangunan, penelitian ini dilakukan. Agar mampu memberikan kontribusi dalam peningkatan kapasitas aparatur pemerintah dalam melakukan perencanaan pembangunan, diperlukan adanya informasi yang dapat menjawab tentang faktor-faktor apa yang menjadi penyebab lemahnya kapasitas aparatur pemerintah daerah dalam melakukan perencanaan pembangunan serta solusi apa yang dapat dilakukan untuk memecahkan akar penyebab permasalahan tersebut.

\section{METODE PENELITIAN}

Artikel ini merupakan hasil penelitian bersifat deskripsi kualitatif yang dilakukan di lingkungan Pemerintah Kota Probolinggo yang dimaksudkan untuk mengetahui akar penyebab terjadinya lemahnya kapasitas aparatur Pemerintah Kota Probolinggo dalam melakukan perencanaan pembangunan. Untuk mengetahui akar penyebab tersebut, penulis melakukan wawancara secara mendalam (in depth) terhadap aparatur pemerintah daerah di beberapa Organisasi Perangkat Daerah (OPD) yang menduduki jabatan di bidang perencanaan. Pemilihan responden dilakukan secara purposive sampling dengan besaran jumlah responden sebanyak 30 orang responden. Seluruh data yang diperoleh dari hasil wawancara secara mendalam (in depth) selanjutnya dianalisis dengan mempergunakan model Spradley. Dengan mempergunakan analisis ini, maka seluruh data akan dilakukan analisis domain, analisis taksonomi, analisis komponen dan analisis tema (Emzir, M.Pd, 2016, 209).

Untuk mengetahui akar penyebab rendahnya kapasitas aparatur pemerintah daerah dalam melakukan perencanaan pembangunan, secara umum data yang dikumpulkan dan dikategorikan ke dalam 4 (empat) aspek, Pertama adalah ada tidaknya kebijakan OPD yang ditujukan untuk menstimuli inovasi dalam perencanaan pembangunan. Kedua, ada tidaknya kebijakan OPD dalam pengembangan kapasitas SDM aparatur pemerintah daerah untuk perencanaan pembangunan. Ketiga, pengetahuan SDM aparatur pemerintah daerah dalam melakukan analisis kebutuhan masyarakat, dan keempat, pengetahuan dan ketrampilan SDM aparatur pemerintah daerah dalam menyusun perencanaan pembangunan.

\section{HASIL DAN PEMBAHASAN \\ Kebijakan Pemerintah Kota Probolinggo Untuk Menstimuli Perencanaan Pembangunan}

Inovasi dalam perencanaan merupakan aspek terpenting untuk mencapai tujuan (goals) dan sasaran 
(objectives). Inovasi dapat dipengaruhi oleh kemampuan individual perencana. Namun ketergantungan pada kemampuan individu dalam menghasilkan inovasi tentunya akan berpengaruh pada masa depan keberlanjutan inovasi di masa depan. Oleh karena itu seharusnya inovasi bukan dilahirkan dari kemampuan individu, tetapi oleh keberadaan sistem yang diciptakan dalam OPD untuk mendorong inovasi oleh sumber daya manusia yang ada.

Menurut Metcalfe, yang dimaksudkan dengan inovasi adalah sebuah sistem yang menghimpun berbagai institusi untuk berkontribusi, baik Bersama maupun individu, untuk pengembangan dan difusi teknologi baru dan menyediakan kerangka kerja untuk mengimplementasikannya. Dalam konteks ini pemerintah daerah perlu membentuk dan mengimplementasikan kebijakan yang dapat mempengaruhi proses inovasi. Dengan demikian, sistem inovasi merupakan suatu sistem dari lembaga yang saling berkaitan untuk menciptakan, menyimpan, dan mengalihkan (mentransfer) pengetahuan, keterampilan yang menentukan teknologi baru (Rivai, 2007).

Jika dikaitkan dengan konteks yang lebih luas, kebijakan OPD untuk menstimulus inovasi tersebut merupakan bagian dari manajemen pengetahuan (knowledge management) dalam institusi pemerintahan. Penerapan manajemen pengetahuan (knowledge management) di organisasi pemerintahan hampir sama dengan organisasi swasta, hanya saja pada organisasi pemerintahan tujuan akhir dari inovasi adalah peningkatan layanan publik.

Dengan demikian tujuan penerapan manajemen pengetahuan (knowledge management) pada organisasi pemerintahan adalah untuk mempermudah proses penciptaan, pengumpulan, penyimpanan, dan berbagitukar pengetahuan (knowledge sharing), menutup kesenjangan pengetahuan antara satu pegawai dengan pegawai lainnya dan meningkatkan kemampuan organisasi dalam mengelola aset intelektual, pengetahuan dan pengalaman yang ada.

Birokrasi pemerintahan daerah sebenarnya telah didorong untuk melaksanakan manajemen pengetahuan. Manajemen pengetahuan dalam pemerintahan telah diatur dalam Peraturan Menteri Pemberdayaan Aparatur Negara dan Reformasi Birokrasi Nomor 14 Tahun 2011 tentang Pedoman Pelaksanaan Program Manajemen Pengetahuan (Permen PAN\&RB No. 14 Tahun 2011).

Berdasarkan Permen PAN\&RB No. 14 Tahun 2011, berbagi pengetahuan adalah proses menyebarkan dan membuat pengetahuan tersedia untuk berbagai kalangan yang membutuhkan di dalam organisasi penggunanya. Proses berbagi dapat terbentuk melalui proses sosial pada kultur organisasi yang menghargai aktivitas berbagi pengetahuan. Proses tersebut dapat berlangsung secara tradisional melalui diskusi dan kolokium, maupun melalui medium modern dengan berbasiskan teknologi. Dengan adanya Manajemen Pengetahuan, OPD dapat belajar untuk melaksanakan aktivitas yang semakin baik dari waktu ke waktu. Kemampuan individu-individu dalam OPD akan memanfaatkan pengetahuan kolektif yang mereka miliki sekaligus dapat menghindari terjadinya pengulangan proses, termasuk di dalamnya kemampuan untuk belajar dan mengevaluasi tindakan yang telah dilakukan, yang pada gilirannya akan mempengaruhi kinerja organisasi itu sendiri.

Berdasarkan hasil wawancara dan penelusuran dokumen yang dilakukan, teridentifikasi 3 (tiga) kondisi yang terkait dengan belum maksimalnya stimulasi inovasi dalam perencanaan pembangunan di Kota Probolinggo. Pertama, tidak adanya kebijakan pendokumentasian secara sistematis seluruh pengalaman-pengalaman dalam menjalankan program kerja, sekaligus kebijakan yang memastikan aparatur menuliskan inovasi yang dilakukan di tahun lalu. Kemampuan untuk mengakumulasi pengetahuan dan keterampilan ini sungguh penting dalam rangka menjadikan Pemerintah Kota Probolinggo menjadi pusat pembelajaran (learning center).

Kemampuan menuliskan pengalaman, mendokumentasikannya secara sistematis, mendialogkannya dengan berbagai pihak yang mampu memberi masukan berharga menjadi sangat penting di dalam proses membangun pengetahuan dan keterampilan dari pengalaman empiris ini. Dokumentasi tertulis sebagai bahan pembelajaran dari perencanaan sebelumnya selama ini mengacu kepada LAKIP dan Laporan Kegiatan. Namun LAKIP dan Laporan Kegiatan merupakan dokumen yang bersifat institusional, sehingga tidak merepresentasikan pengetahuan dan ketrampilan di level individu pegawai.

Kedua, tidak adanya strategi agar aparatur Pemerintah Kota Probolinggo mampu menghasilkan dokumen khusus tentang inovasi dari pengalaman empiris melaksanakan program-program pembangunan. Pedoman dalam inovasi pelayanan publik, salah satunya dalam aspek dokumentasi, sebenarnya telah diatur dalam Peraturan Menteri Pemberdayaan Aparatur Negara dan Reformasi Birokrasi Nomor 31 Tahun 2014 tentang Pedoman Inovasi Pelayanan Publik. Namun dalam faktanya, hingga saat ini belum ada upaya pendokumentasian pengalaman dalam menjalankan program kerja maupun inovasi yang dilakukan oleh Pemerintah Kota Probolinggo. Kondisi ini juga belum terwujud dalam kebijakan Pemerintah Kota Probolinggo yang mendorong aparaturnya menghasilkan dokumen khusus tentang inovasi. Pembuktian ada tidaknya strategi tersebut dapat dilihat pada ada tidaknya publikasi khusus berbentuk buku, yang menceritakan tentang inovasi penting OPD sebagai luarannya.

Dari hasil wawancara dengan responden kunci, diketahui saat ini usulan inovasi tidak disampaikan tertulis secara komprehensif. Pengalaman pada salah satu OPD menunjukkan bahwa inovasi dalam perencanaan pembangunan hanya disampaikan secara lisan dalam rapat staf. Usulan tersebut kemudian akan dibahas dalam rapat staf. Metode ini tentunya memiliki kelemahan dalam pendokumentasian usulan tersebut yang pada akhirnya inovasi tersebut tidak dapat dikaji dan diimplementasikan.

Ketiga, dari hasil wawancara dengan beberapa responden diketahui saat ini di Pemerintah Kota Probolinggo belum memiliki mekanisme sistem yang memungkinkan pegawai berbagi dan mentransfer pengetahuan dan keterampilannya kepada aparatur lain, 
baik di lingkungan OPD yang sama atau antar OPD. Berbagi pengetahuan merupakan salah satu metode dalam knowledge management yang dapat dipergunakan untuk memberikan kesempatan kepada aparatur pemerintah daerah untuk berbagi pengalaman dan ide pembangunan. Oleh karena itu perlu adanya komunikasi berupa dialog antar aparatur OPD maupun antar OPD untuk membagi pengetahuan, pengalaman dan ide.

Transfer pengetahuan dan ketrampilan pada sebagian besar OPD tidak dilakukan berdasarkan sistem, tetapi dilakukan berdasarkan kebutuhan pada waktu tertentu. Jika terdapat pelatihan atau bimbingan teknis yang dibutuhkan oleh aparatur OPD, maka setiap aparatur yang terkait dengan bidang dari pelatihan tersebut ditugaskan untuk mengikuti pelatihan. Mekanisme penugasan tersebut hanya didasarkan pada kebijakan internal OPD dan lebih banyak disebabkan oleh pengamatan kebutuhan oleh pimpinan dan bukan karena adanya rencana pengembangan kapasitas SDM aparatur di OPD. Rekomendasi aparatur yang ditugaskan mengikuti kegiatan peningkatan kapasitas sebagai bagian dari transfer pengetahuan inovasi hanya didasarkan pada bidang yang ditempati oleh aparatur tersebut.

Setelah mengikuti pelatihan/lokakarya peningkatan kapasitas, dari hasil wawancara diketahui tidak adanya mekanisme untuk melakukan transfer pengetahuan kepada aparatur lain. Transfer pengetahuan dilakukan secara informal antar pribadi aparatur. Sebagai akibatnya tidak terjadi penyebarluasan pengetahuan pada sesama aparatur pemerintah daerah.

Dalam pandangan aparatur Pemerintah Kota Probolinggo, sistem untuk berbagi dan transfer pengetahuan bukan menjadi tanggungjawab pribadi aparatur atau OPD yang memiliki tugas pokok dan fungsi melakukan pengembangan kapasitas aparatur. Menurut responden, tanggungjawab transfer pengetahuan menjadi tugas pokok dan fungsi dari Badan Kepegawaian dan Pengembangan SDM.

Seharusnya proses berbagi dan transfer pengetahuan oleh aparatur dapat dilakukan melalui mekanisme sosialisasi yang terdokumentasikan. Upaya pendokumentasian hasil kegiatan knowledge sharing melalui sosialisasi yang sudah dilakukan aparatur itu, perlu mendapatkan perhatian khusus sehingga nantinya menjadi modal organizational knowledge. Pendokumentasian hasil knowledge sharing yang baik diharapkan mampu mendorong proses pembelajaran yang berkelanjutan. Mekanisme transfer pengetahuan dan inovasi tersebut bukan hanya dapat dilakukan dalam internal OPD saja, tetapi juga lintas OPD. Melalui pendekatan tersebut diharapkan perkembangan inovasi dapat terjadi secara merata di setiap OPD.

\section{Kebijakan Pengembangan Kapasitas Aparatur dalam Perencanaan Pembangunan}

Secara umum tujuan pengembangan kapasitas tentu agar individu, organisasi maupun juga sistem yang ada dapat dipergunakan secara efektif dan efisien untuk mencapai tujuan dari individu maupun organisasi tersebut. Dalam konteks pembangunan, tidak ada tujuan lain selain untuk menciptakan tata kepemerintahan yang baik atau yang lebih dikenal dengan good governance. Suatu kondisi kepemerintahan yang yang dicita-citakan semua pihak dan mampu menjawab persoalanpersoalan dunia saat ini.

Jika ditinjau dari perspektif sistem, penguatan kapasitas aparatur pada hakekatnya merupakan pendayagunaan dan pembinaan keseluruhan sistem administrasi pemerintahan daerah yang berfokus pada pengembangan komponen-komponen dasar. Komponen-komponen dasar tersebut meliputi kapasitas kelembagaan, kapasitas kepegawaian dan mekanisme ketatalaksanaan yang kondusif dan sinergi. Pengembangan kapasitas komponen-komponen tersebut akan mewujudkan sistem organisasi dan manajemen aparatur pemerintah daerah yang mampu menyelenggarakan tugas dan fungsi pemerintahan serta pembangunan secara optimal.

Pengembangan kapasitas dapat didefinisikan sebagai sebuah proses untuk meningkatkan kemampuan individu, kelompok, organisasi, komunitas atau masyarakat untuk menganalisa lingkungannya; mengidentifikasi masalah-masalah, kebutuhankebutuhan, isu-isu dan peluang-peluang; memformulasi strategi-strategi untuk mengatasi masalah-masalah, isuisu dan kebutuhan-kebutuhan tersebut, dan memanfaatkan peluang yang relevan. Merancang sebuah rencana kerja, serta mengumpulkan dan menggunakan secara efektif, dan atas dasar sumber daya yang berkesinambungan untuk mengimplementasikan, memonitor, dan mengevaluasi rencana kerja tersebut, serta memanfaatkan umpan balik sebagai pelajaran (Capacity Need Assessment: A Conceptual Framework, 2001).

Berdasarkan wawancara dengan beberapa aparatur Pemerintah Kota Probolinggo, ditemukan tidak adanya kebijakan pengembangan kapasitas perencanaan pembangunanan yang sifatnya jangka panjang untuk aparatur yang berada di setiap OPD. Tidak adanya kebijakan tersebut berimplikasi pada tidak dapat terukurnya implementasi pengembangan kapasitas aparatur dalam perencanaan pembangunan. Selain itu juga berimplikasi pada tidak adanya monitoring, evaluasi, dan peninjauan kebijakan di daerah.

Saat ini upaya pengembangan kapasitas merupakan bagian yang penting di dalam berbagai aspek aparatur pemerintahan. Dalam kehidupan seharihari pengembangan kapasitas misalnya dilaksanakan dengan pendidikan, baik secara formal maupun informal. Dalam pemerintahan pengembangan kapasitas aparatur pemerintah juga penting untuk meningkatkan performa aparatur dalam menjalankan tugasnya sebagai abdi negara, dan juga regulasi dan deregulasi kebijakan pemerintahan. Dalam konteks pembangunan secara keseluruhan, upaya pengembangan kapasitas menjadi bagian yang tidak terpisahkan. Dengan kata lain tidak mungkin terjadi suatu proses pembangunan/pengembangan dalam hal apapun tanpa upaya pengembangan kapasitas bagi pelaku maupun juga sistem yang mengaturnya.

Berdasarkan hasil wawancara terhadap beberapa responden di OPD di lingkungan Pemerintah Kota 
Probolinggo, sebagian besar responden beranggapan bahwa kebijakan perencanaan pengembangan kapasitas merupakan tanggung jawab Badan Kepegawaian dan Pengembangan SDM Kota Probolinggo. Organisasi Perangkat Daerah (OPD) hanya melaksanakan kebijakan pengembangan kapasitas yang telah dibuat oleh Badan Kepegawaian dan Pengembangan SDM.

Pendapat lain menunjukkan adanya pandangan bahwa peningkatan kapasitas aparatur dalam perencanaan pembangunan seharusnya menjadi tanggung jawab Bappeda \& Litbang Kota Probolinggo. Jika dikaitkan dengan konteks perencanaan pembangunan, maka seharusnya Bappeda \& Litbang Kota Probolinggo memfasilitasi adanya pendampingan perencanaan program dalam rangka peningkatan kapasitas SDM yang menjabat sebagai Kasubag Program dan Perencanaan. Tidak adanya upaya peningkatan kapasitas Kasubag Program dan Perencanaan di OPD berimplikasi pada minimnya pengetahuan dan ketrampilan Kasubag Program dalam melakukan perencanaan pembangunan. Selama ini pengetahuan dan ketrampilan Kasubag Program lebih banyak diperoleh melalui transfer informasi di antara Kasubag Program dan Perencanaan dalam melakukan perencanaan pembangunan.

Lebih daripada itu, kegiatan pengembangan kapasitas saja tidak cukup untuk meningkatkan keterampilan/kemampuan dari aparatur. Kapasitas aparatur dapat berkembang ketika pengetahuan dan keterampilan baru yang dimilikinya diaplikasikan dalam kerja sehari-hari dan secara berkelanjutan melakukan refleksi tentang inovasi dan kegiatan program pembangunan yang benar-benar terimplementasi dengan baik serta aspek apa saja yang perlu dilakukan perbaikan. Hasil refleksi atas pengalaman tersebut diharapkan dapat mengembanggkan pengetahuan dan keterampilan menjadi "kemampuan/keahlian".

\section{Pengetahuan dan Ketrampilan SDM terhadap Analisis Kebutuhan Masyarakat}

Analisis kebutuhan masyarakat merupakan kegiatan utama yang melandasi pembangunan masyarakat, alasan pokoknya adalah menghindari terjadinya kesalahan definisi kebutuhan (needs) dengan keinginan (wants). Meski perbedaan antara keduanya cukup kontras, analisis penting dilakukan, karena kebutuhan terkait dengan konsep kenyataan dan prioritas. Kebutuhan dirumuskan untuk dipenuhi berdasarkan urutan kepentingannya. Selain itu, praktik pemenuhan kebutuhan mengikuti kebutuhan yang dirasakan, sedangkan kebutuhan yang dirasakan seringkali berbeda dengan kebutuhan nyata.

Dalam konteks pemerintahan, pengetahuan SDM dalam analisis kebutuhan masyarakat dibutuhkan untuk menghasilkan perencanaan pembangunan yang responsif dan akurat. Mendasarkan pada hasil wawancara dengan responden, sebagian besar OPD menunjukkan bahwa analisis terhadap kebutuhan masyarakat sumbernya terbatas pada apa yang diperoleh dalam Musrenbang. Di sisi lain, kebutuhan yang disampaikan Musrenbang seringkali tidak menyentuh akar permasalahan. Dampaknya adalah banyak kebutuhan masyarakat yang diselesaikan dalam bentuk pemberian hibah. Realitas ini menunjukkan masih lemahnya kemampuan analisis beberapa aparatur di OPD dalam menganalisis kebutuhan masyarakat.

Pada tingkatan staf juga seringkali ditemukan tidak adanya kemampuan untuk menganalisis kaitan Renstra OPD dengan RPJMD dan Sustainable Development Goals (SDGs). Hal ini disebabkan tidak adanya pemerataan pengetahuan dalam menganalisis RPJMD dan bagaimana menerjemahkan RPJMD ke dalam tingkatan kegiatan program di setiap OPD. Mendasarkan pada hasil wawancara dengan responden diketahui seharusnya setiap staf juga memiliki pengetahuan yang komprehensif terhadap RJPMD sehingga seluruh aparatur pemerintahan memiliki kesamaan pandangan tentang tujuan yang ingin dicapai dalam 5 (lima) tahun mendatang.

Keterbatasan waktu dalam melakukan analisis kebutuhan masyarakat secara mendalam juga turut berpengaruh. Keterbatasan atau sempitnya waktu tersebut mengakibatkan staf lebih banyak bergantung pada apa yang diperoleh dari Musrenbang. Padahal analisis kebutuhan tidaklah cukup hanya menggunakan satu teknik untuk merumuskan kebutuhan masyarakat, dalam hal ini melalui Musrenbang. Analisis kebutuhan masyarakat harus dilakukan trangulasi dengan cara menggunakan beberapa macam teknik dan menggali data dari berbagai sumber dalam masyarakat.

Berdasarkan informasi yang diperoleh melalui wawancara, sebenarnya telah disadari bahwa usulan yang diperoleh dalam Musrenbang seringkali tidak menjawab akar permasalahan yang ada dalam masyarakat. Masyarakat pada umumnya tidak mampu menangkap apa yang menjadi kebutuhan riil sehingga apa yang disampaikan seringkali keinginan jangka pendek atau kebutuhan yang bersifat artifisial

Jika dianalisis lebih lanjut, kelemahan dalam kemampuan menganalisis kebutuhan masyarakat dalam perencanaan pembangunan bersumber dari lemahnya penguasaan data. Lemahnya penguasaan data dapat disebabkan oleh keterbatasan pengetahuan sumber daya terhadap data, atau minimnya data yang dimiliki dan dibutuhkan OPD sebagai sumber informasi dalam menganalisis kebutuhan masyarakat.

Minimnya data dalam dalam hal ini adalah ketersediaan data statistik sesuai dengan kebutuhan perencanaan pembangunan daerah. Misalnya, data statistik yang menjadi indikator SDGs yang berkaitan dengan bidang kerja OPD. Kelemahan kemampuan menganalisis data, misalnya dalam bentuk kemampuan menganalisis data/informasi yang berkaitan dengan Indeks Pembangunan Manusia (IPM) serta memanfaatkannya untuk menyusun orientasi dan prioritas pembangunan yang menjadi tanggungjawab OPD.

Dengan kondisi itu, seharusnya aparatur di setiap OPD didorong untuk terlibat dalam pengumpulan data secara langsung. Terutama data-data empiric yang penting dalam menganalisis kebutuhan masyarakat. Keterlibatan langsung dalam pengumpulan data nantinya dapat mendorong perkembangan penguasaan staf terhadap data-data yang penting di bidang kerjanya masing-masing. 


\section{Pengetahuan dan Ketrampilan SDM Dalam Perencanaan Pembangunan}

Aspek terpenting dalam perencanaan pembangunan adalah pengetahuan dan ketrampilan sumber daya manusia yang bertindak sebagai perencana. Jika SDM tersebut tidak memiliki pengetahuan dan ketrampilan dalam perencanaan maka besar kemungkinan rencana yang disusun tidak memiliki kualitas yang baik. Oleh karena itu, idealnya setiap aparatur yang ada di Pemerintah Kota Probolinggo memiliki pengetahuan yang baik dalam menganalisis perencanaan pembangunan.

Bukti dari lemahnya pengetahuan dan ketrampilan SDM dalam perencanaan pembangunan di Pemerintah Kota Probolinggo adalah belum adanya kesatuan pemahaman tentang bagaimana sebenarnya sinkronisasi perencanaan program. Mendasarkan pada hasil wawancara dengan beberapa responden, diketahui beberapa OPD tidak mengetahui sejauhmana sinkronisasi Renstra OPD yang disusun jika dibandingkan dengan RPJMD. Beberapa OPD memiliki kekhawatiran bahwa Renstra yang disusun justru tidak sesuai dengan RPJMD. Kekhawatiran tersebut juga disebabkan lemahnya pengetahuan dan ketrampilan staf dalam membuat perencanaan.

Jika salah satu pendekatan dalam perencanaan pembangunan adalah top-down, maka seharusnya dilaksanakan evaluasi dan sinkronisasi Renstra dengan RPJMD. Hasil evaluasi dan sinkronisasi tersebut kemudian disampaikan kepada SKPD masing-masing untuk dilaksanakan peninjauan. Namun berdasarkan informasi beberapa responden di OPD, tidak diketahui adanya hasil evaluasi dan sinkronisasi antara Renstra dan RPJMD. Selain itu juga dikeluhkan minimnya asistensi maupun pelatihan dari OPD yang membidangi perencanaan pembangunan untuk menyusun Renstra OPD.

Permasalahan lain yang turut berpengaruh kepada pengetahuan dan ketrampilan aparatur dalam perencanaan adalah intensitas mutasi. Tingginya intensitas mutasi dianggap menyulitkan OPD untuk meningkatkan pengetahuan dan ketrampilan staf. Jika dikaitkan dengan kebijakan pengembangan kapasitas SDM, intensitas mutasi juga menyulitkan implementasi pengembangan kapasitas karena pemerataan kapasitas sumber daya manusia akan sulit untuk dicapai.

Selain aspek pengetahuan, dalam aspek ketrampilan seorang aparatur pemerintah harus mampu menjadwalkan, merencanakan dan memfasilitasi dengan baik dan efektif proses-proses untuk mendapat usulan/masukan/kritik/saran dari masyarakat terhadap rencana dan anggaran pembangunan, proses pembangunan, dan hasil pembangunan. Adanya ketrampilan manajerial dalam perencanaan tersebut dapat berperan besar sehingga berbagai masukan tersebut dapat dimanfaatkan secara maksimal untuk penyempurnaan perencanaan.

Praktik perencanaan pembangunan di berbagai OPD menunjukkan bahwa ketrampilan tersebut telah cukup dimiliki hingga pada tingkatan staf. Tugas penjadwalan, perencanaan, dan berperan sebagai fasilitator tersebut bukan hanya dimonopoli oleh tingkat pejabat struktural OPD. Staf telah dilibatkan dalam proses tersebut sehingga terlatih dalam mengambil peran sebagai fasilitator.

Staf fungsional seharusnya juga perlu memiliki ketrampilan mengumpulkan dan menganalisis data/informasi berkaitan dengan Indeks Pembangunan Manusia (IPM), serta memanfaatkannya untuk menyusun orientasi dan prioritas pembangunan yang menjadi tanggung jawab OPD. Ketrampilan staf selama ini terbatas pada kemampuan mengumpulkan data. Namun kemampuan menganalisis data tersebut dinilai kurang. Hal ini disebabkan terbatasnya penguasaan staf terhadap bidang kerja dan mengkaitkannya dengan data-data yang dimiliki.

Bagi beberapa staf fungsional, bidang kerjanya dalam OPD merupakan hal baru yang tidak pernah dipelajari sebelumnya. Misalnya terkait bidang pemberdayaan masyarakat, tidak semua staf memiliki pengetahuan tentang konsep dan pendekatan dalam pemberdayaan masyarakat. Padahal pengetahuan tersebut tentunya menjadi wacana dasar sebelum mampu menyusun sebuah perencanaan pembangunan di bidang pemberdayaan masyarakat.

Berbagai kondisi terkait pengetahuan dan ketrampilan sumber daya manusia di atas menunjukkan bahwa tidak adanya kebijakan pengembangan kapasitas berimplikasi pada pengetahuan dan ketrampilan sumber daya manusia. Tidak adanya kebijakan pengembangan kapasitas yang sistematis sesuai bidang kerja masingmasing OPD berdampak pada pentingnya inisiatif pembelajaran mandiri (self learning) oleh setiap staf fungsional di OPD. Jika staf fungsional di OPD tidak memiliki inisiatif dalam pembelajaran mandiri untuk meningkatkan kapasitasnya, maka akan sulit mewujudkan pemerataan kapasitas antar OPD maupun di internal OPD. Guna mengatasi permasalahan tersebut, diperlukan adanya peningkatan kapasitas SDM aparatur pemerintah daerah dalam konteks tugas, pokok dan fungsinya di dalam OPD melalui diklat dengan berorientasi pada standar kompetensi jabatan dan globalisasi manajemen yang disesuaikan dengan kebutuhan OPD (Mulyono, 2015).

Di sisi lain, setiap OPD tidak dapat bergantung pada pengetahuan dan ketrampilan staf fungsional tertentu yang menonjol kapasitasnya. Jika terjadi mutasi pegawai yang menonjol akan berdampak pada keberlanjutan pengetahuan dan ketrampilan tersebut di internal OPD. Oleh karena itu yang perlu diwujudkan adalah pemerataan pengetahuan dan ketrampilan dalam perencanaan di setiap OPD. Pemerataan tersebut tidak dapat diwujudkan secara sporadis melalui kebijakan pimpinan masing-masing OPD, tetapi harus melalui desain besar kebijakan pengembangan kapasitas (by design). Selain daripada itu, pemerintah daerah juga perlu untuk mengembangkan metode baru untuk sistem mutasi aparatur yang mampu mengintegrasikan sistem terbuka dan tertutup dalam pengisian jabatan, tanpa harus menghilangkan pengembangan karir aparatur di lingkungan kerjanya (Sudrajat, 2014).

Pengembangan kapasitas yang dilakukan juga seharusnya tidak berorientasi pada kebutuhan birokrasi saja. Potensi aparatur juga harus dikembangkan sepenuhnya secara holistik. Sikap mental, etos kerja dan kreativitas yang nantinya mendorong inovasi juga 
harus dikembangkan. Pengembangan tersebut diharapkan dapat mendorong terciptanya kondisi aparatur yang peka terhadap aspirasi masyarakat dan kreatif serta mempunyai arah dalam menyusun program kerja.

Memperhatikan pada hasil temuan data di lapangan seperti yang telah diuraikan di atas, maka teridentifikasi beberapa faktor yang menjadi penyebab lemahnya kemampuan Perencanaan Program Pembangunan oleh apartur di lingkungan Pemerintah Kota Probolinggo. Beberapa faktor tersebut adalah:

\section{Belum efektifnya mekanisme evaluasi}

Tidak ubahnya manajemen pada organisasi privat, manajemen organisasi publik juga memerlukan adanya evaluasi dalam setiap proses manajerialnya. Evaluasi pada organisasi publik diperlukan untuk peningkatan pelayanannya terhadap masyarakat secara berkelanjutan. Kebijakan mutu tata kelola pemerintahan yang harus melakukan proses evaluasi telah ditetapkan dalam PP No. 60 tahun 2008 tentang Sistem Pengendalian Internal Pemerintah. Dalam PP tersebut telah diatur bahwa dalam proses manajerialnya, organisasi pemerintah harus secara konsisten dan berkelanjutan menerapkan siklus Perencanaan, Pelaksanaan, Evaluasi, Pengendalian dan Peningkatan (PPEPP).

Berefleksi pada hasil temuan data di lapangan, diketahui walaupun telah dituangkan dalam kebijakan Pemerintah melalui PP No. 60 Tahun 2008, namun mekanisme PPEPP tersebut belum dapat berjalan secara efektif di lingkungan Pemerintah Kota Probolinggo.

Kegiatan program

yang

telah diimplementasikan belum cukup maksimal untuk didokumentasikan, dievaluasi dan dikomunikasikan secara internal dengan seluruh pimpinan dan staf pelaksana. Evaluasi implementasi kegiatan program hanya dilakukan melalui mekanisme pengawasan yang dilakukan oleh Inspektorat dan bukan dilakukan melalui mekanisme evaluasi internal OPD. Evaluasi yang dilakukan lebih memfokuskan pada konsistensi perencanaan dan pelaksanaan anggaran pembangunan. Bukan pada efektifitas implementasi kegiatan program dan outcome yang dihasilkan.

Mendasarkan pada hasil temuan data di lapangan juga diketahui bahwa hingga saat ini di lingkungan Pemerintah Kota Probolinggo belum secara maksimal adanya forum yang secara efektif melakukan evaluasi dan sinkronisasi perencanaan yang ada di dalam dokumen RPJMD, Renstra OPD dan Renja OPD. Dengan tidak adanya evaluasi tersebut, dimungkinkan tidak terjadi sinkronisasi dan konsistensi Perencanaan Pembangunan dengan pencapaian visi dan misi Pemerintah Kota.

\section{Tidak ada pendokumentasian dan pengkomunikasian hasil kegiatan program pembangunan \\ Pendokumentasian hasil implementasi} kegiatan program sangat penting sebagai bahan pembelajaran dari perencanaan. Dengan didokumentasikannya hasil perencanaan dan pelaksanaan kegiatan program, maka dapat dijadikan pembelajaran bagi aparatur pemerintahan yang lain dalam menyusun sebuah perencanaan pembangunan yang bersifat inovatif.

Tidak adanya pengkomunikasian juga terjadi pada hasil pelatihan dan atau pengembangan kapasitas SDM yang diikuti oleh aparatur pemerintah. Seharusnya hasil proses pembelajaran yang telah diikuti oleh seorang aparatur pemerintah dapat disebarluaskan pada aparatur pemerintah dalam internal OPD. Hal ini dilakukan sebagai upaya penyebarluasan informasi, pengetahuan dan ketrampilan kepada aparatur pemerintah yang lain.

\section{Tidak Adanya Rencana Pengembangan Sumberdaya Manusia}

Mendasarkan pada hasil temuan data di lapangan diketahui saat ini tidak adanya kebijakan di tingkat OPD yang dipergunakan sebagai dasar dalam melakukan upaya pengembangan sumberdaya manusia, baik dalam aspek perencanaan, pelaksanaan dan evaluasi kegiatan program. Diperlukan adanya identifikasi kompetensi dan rencana pengembangan kompetensi aparat dalam merencanakan dan melaksanakan tugas pokok dan fungsi (TUPOKSI) dan focus utama layanan Organisasi Pemerintah Daerah (OPD).

Saat ini pengembangan kapasitas SDM dilakukan oleh Badan Kepegawaian Daerah dan Pengembangan SDM Kota Probolinggo yang lebih merujuk pada pengembangan kapasitas SDM dalam etika organisasi serta kemampuannya sebagai aparat birokrasi secara umum dan tidak berfokus pada kompetensi aparat dalam melaksanakan tugas, pokok dan fungsi serta layanan OPD.

Dengan tanpa adanya pengembangan kapasitas SDM yang berfokus pada kompetensi terkait dengan focus utama layanan OPD, berakibat lemahnya kemampuan SDM dalam melakukan analisis data yang dipergunakan untuk perencanaan program pembangunan.

Pengembangan kapasitas SDM dalam konteks pemerintah memang diperlukan untuk mendukung prinsip Good Governance seperti efisiensi, efektivitas dan tanggap (Ginting \& Daeli, 2012). Perlu pula diperhatikan dalam pengembangan kapasitas SDM aparatur pemerintah daerah adalah teralokasikannya anggaran pengembangan kapasitas SDM untuk perencanaan pembangunan dalam APBD (Ashari, 2010).

Pentingnya program pelatihan bagi SDM aparatur Pemerintah Kota Probolinggo secara berkelanjutan agar memiliki kompetensi dalam perencanaan pembangunan juga telah dibuktikan dari hasil penelitian yang dilakukan oleh Pakpahan et.al (2014) yang mengatakan bahwa kapasitas aparatur dalam bekerja untuk mencapai tujuan organisasi dipengaruhi oleh pelatihan.

\section{Lemahnya Data Input Perencanaan Program}

Perencanaan kegiatan program pembangunan hingga saat ini masih mengandalkan pada hasil 
Musrenbang. Ironisnya kebutuhan yang disampaikan melalui mekanisme Musrenbang terkadang tidak menyentuh pada akar permasalahan dan kebutuhan nyata masyarakat. Kelemahan data sebagai input utama dalam perencanaan program pembangunan juga ditemukan dari hasil penelitian yang dilakukan oleh Wilonoyudo (2007), dimana sangat sedikit data yang dapat dihimpun sebagai pertimbangan rasional perencanaan pembangunan.

Aparat juga belum secara optimal mempergunakan data yang dapat diperoleh dari berbagai pihak yang memiliki relevansi dengan perencanaan program. Sebagai akibatnya, kegiatan program yang direncanakan selalu bersifat rutin tanpa adanya inovasi.

Dibutuhkan responsivitas dari aparatur pemerintah daerah untuk mampu mengenali kebutuhan masyarakat, menyusun agenda pembangunan dan prioritasnya serta mengembangkan program pembangunan sesuai dengan aspirasi dan kebutuhan masyarakat (Suderajat, 2014). Pentingnya dukungan data ini seperti yang dikatakan oleh Kuncoro (2018), dimana salah satu faktor alasan gagalnya perencanaan pembangunan adalah tidak adanya dan/atau dukungan data yang memadai serta dapat dipercaya.

\section{Cepatnya Intensitas Mutasi Aparat Birokrasi}

Salah satu faktor yang cukup berpengaruh terhadap efektifitas perencanaan program adalah terlalu cepatnya intensitas mutasi aparatur untuk mengisi kekosongan posisi. Cepatnya mutasi seorang aparatur pemerintah dari OPD satu ke OPD lainnya menjadikan belum tuntasnya pemahaman aparatur tersebut akan tugas pokok dan fungsinya. Seharusnya mutasl aparatur pemerintah dilakukan secara transparan dan sebagai bentuk penghargaan, bukan dengan pertimbangan sekedar pengisian jabatan semata (Apriani, 2015)

Kondisi ini diperparah dengan tidak didokumentasikan dan dikomunikasikannya hasil perencanaan dan pelaksanaan program yang dapat dijadikan bahan belajar bagi aparatur penggantinya.

\section{SIMPULAN}

Memperhatikan isu permasalahan diatas, maka solusi dan arah kebijakan dalam Peningkatan Kapasitas Aparatur Pemerintah dalam Perencanaan Pembangunan di lingkungan Pemerintah Kota Probolinggo adalah sebagai berikut:

1. Untuk isu belum adanya mekanisme evaluasi efektifitas perencanaan program pembangunan dan pencapaian outcome, diperlukan adanya kebijakan yang dimaksudkan untuk :

a. mendokumentasikan hasil pelaksanaan kegiatan program,

b. melakukan evaluasi pencapaian outcome kegiatan program pembangunan,

c. mengkomunikasikan hasil evaluasi pencapaian program pembangunan secara rutin kepada aparatur pemerintah, d. menjadikan pencapaian outcome kegiatan sebagai salah satu tolok ukur evaluasi kinerja OPD,

e. melakukan evaluasi pencapaian renstra dan renja OPD secara periodic pada setiap akhir tahun anggaran,

f. melakukan sinkronisasi perencanaan program renja OPD dengan mengacu pada renstra OPD dan RPJMD Kota Probolinggo.

2. Untuk isu belum optimalnya sistem pendokumentasian hasil pelaksanaan kegiatan program, diperlukan kebijakan dari Pemerintah Kota Probolinggo untuk melakukan pengembangan sistem informasi pelaporan hasil pelaksaaan kegiatan program berbasis pada teknologi informasi yang dapat diakses oleh semua pihak,

3. Sedangkan untuk isu belum cukup optimalnya kapasitas SDM aparatur Pemerintah Kota Probolinggo dalam perencanaan pembangunan, maka diperlukan adanya dukungan kebijakan di lingkungan Pemerintah Kota Probolinggo yang dimaksudkan untuk:

a. menyusun road map pengembangan SDM yang menjadi satu kesatuan dengan analisis jabatan di lingkungan OPD,

b. menyelenggarakan pelatihan secara periodic untuk meningkatkan kompetensi SDM dalam perencanaan kegiatan program pembangunan,

c. memperkuat sinergitas data perencanaan pembangunan dengan berbagai stakeholders terkait.

\section{DAFTAR PUSTAKA}

Apriani, T. (2015). Peningkatan Kemampuan Sumber Daya Manusia Aparatur di Kabupaten Serang. Jurnal Bina Praja, Vol. 7 No. 4, 295.

Ashari, E. T. (2010). Reformasi Pengelolaan SDM Aparatur, Prasyarat Tata Kelola Birokrasi Yang Baik. Jurnal Borneo Administrator, Vol. 6 No. 2, 10.

Capacity Need Assessment: A Conceptual Framework. (2001). ACBF Newsletter Vo. 2, 9 - 12.

Cheema, S. G., \& Rondinelli, D. A. (1983). Decentralization and Development: Policy Implementation in Developing Countries. London: Sage Publication Inc.

Emzir, M.Pd, P. D. (2016). Metodologi Penelitian Kualitatif, Analisis Data. Jakarta: Rajawali Pers.

Ginting, Y., \& Daeli, S. P. (2012, Juni). Pengembangan Kapasitas Aparatur Pemerintah Daerah di Era Otonomi (Studi Kasus: Pemerintah Daerah Kabupaten Samosir). Jurnal Bina Praja Vol. 2, 107.

Kuncoro, Ph.D, P. (2018). Perencanaan Pembangunan Daerah, Teori dan Aplikasi. Jakarta: PT. Gramedia Pustaka Utama.

Listyodono, E., \& Purwaningdyah MW. (2008, Juni). Meningkatkan Kompetensi Aparatur Pemerintah Daerah Dalam Mewujudkan Good Governance. Jurnal Kebijakan dan Manajemen PNS, Vol. 2. No. 1, 34. 
Mulyono, A. (2015, Maret). Pengembangan Aparatur Sipil Negara di Daerah. Jurnal Kebijakan dan Manajemen Publik (JKMP), Vol. 3 No. 1, 28.

Pakpahan, E. S., Siswidiyanto, \& Sukanto. (2014). Pengaruh Pendidikan dan Pelatihan Terhadap Kinerja Pegawai (Studi pada Badan Kepegawaian Daerah Kota Malang). Jurnal Administrasi Publik, Vol. 2 No. 1, 116 - 121.

Rivai, V. (2007). Kepemimpinan dan Perilaku Organisasi. Jakarta: PT. Raja Grafindo Persada.

Rondinelli. (1983). Government Decentralization in Comparative. International Review of Administrative No. 1, 93.

Seymour, R., \& Turner, S. (2002, December). Otonomi Daerah: Indonesian's Decentralisation Experiment. New Zealand Journal of Asian Studies, 33-51.

Statistik, B. P. (2017). Jumlah Penduduk Miskin, Persentase Penduduk Miskin dan Garis Kemiskinan. 1970-2017.

Suderajat, H. (2014). Pengembangan Sistem Manajemen Sumber Daya Manusia Aparatur Pemerintah Daerah. Jurnal IImu dan Budaya, Vol. 32 No. 23, 2396.

Sudrajat, T. (2014). Eksistensi Kebijakan Pengisian Jabatan Struktural Dalam Kerangka Pengembangan SDM Aparatur Berbasis Merit. Jurnal Kebijakan dan Manajemen PNS, 70.

Wilonoyudho, S. (2007). Perencanaan Kota Berbasis Manajemen Bencana. Jurnal Teknik Sipil dan Perencanaan, Vol. 9 No. 2, 169. 